\title{
PERANCANGAN APLIKASI ADMINISTRASI SEKOLAH BERBASIS DESKTOP
}

\author{
Ahmad Musyafa \\ Fakultas Teknik, Universitas Pamulang \\ e-mail : dosen00668@unpam.ac.id
}

\begin{abstract}
ABSTRAK
Perkembangan teknologi informasi yang pesat saat ini merupakan salah satu bagian terpenting dalam mendukung eksistensi suatu lembaga pendidikan. SMP Putra Pertiwi merupakan salah satu yayasan swasta yang mendukung eksistensi tersebut. Untuk itu, SMP Putra Pertiwi membutuhkan sitem administari sekolah untuk mempermudah staf Tata Usaha untuk memberikan informasi keuangan secara cepat dan akurat. Salah satu upaya untuk memberikan laporan keuangan siswa dan memberikan informasi keuangan secara up to date kepada ketua yayasan tentang keuangan sekolah. SMP Putra Pertiwi saat ini belum memiliki Aplikasi Administrasi sekolah, sehingga untuk melihat data keuangan memeperlukan waktu yang cukup menghabiskan waktu, karena harus melihat buku besar dan microsoft office sehingga waktu yang diperlukan untuk melihat data keuangan ini cukup lama. Metodologi yang digunakan dalam perencanaan sistem Aplikasi Administrasi di sini adalah watter fall. Kesemuanya ini dipaparkan dalam model arsitektur aplikasi administrasi dan metode pengumpulan data menggunakan wawancara dan observasi. Pada penelitian ini, dicoba untuk menganalisa pokok-pokok bahasan tersebut dan hasilnya ditujukan untuk memberikan saran bagi kepala sekolah SMP Putra Pertiwi supaya lebih meningkatkan kinerja staff Tata Usaha dalam memberikan informasi keuangan melalui aplikasi ini. Disamping itu, pengembangan rancangan sistem informasi ini dengan menggunakan bahasa pemrograman PHP dan basis data MYSQL.
\end{abstract}

Kata Kunci : Eksitensi, Staf tata usaha, Aplikasi Administrasi Sekolah, Buku besar, Water fall

\section{PENDAHULUAN}

Dunia pendidikan merupakan sebuah bagian yang tidak bisa terpisahkan dari kehidupan bermasyarakat pada umumnya. Pendidikan memang selalu identik dengan proses belajar mengajar, karena hal tersebut memang merupakan kegiatan utama dalam dunia pendidikan. Namun di samping kegiatan belajar mengajar ada banyak hal yang mendukung untuk berlangsungnya kegiatan belajar mengajar tersebut. Salah satunya adalah kegiatan pada bagian administrasi. Dapat dilihat bahwa tanpa dukungan kinerja bagian administrasi pada kegiatan mengajar tentunya akan bertambah sulit untuk menciptakan suasana akademik yang stabil.

Bagian administrasi merupakan bagian yang sehari-harinya melakukan kegiatan rutin menulis, menghitung serta mengelola data pada suatu instansi pendidikan.

Pengembangan sistem informasi berbasis komputer sudah sering kita jumpai hampir setiap perusahaan, instansi pemerintah maupun lembaga pendidikan sebagai sarana pendukung yang tidak kalah pentingnya, yang bisa dipergunakan untuk pengolahan data mengenai ketepatan di dalam pelayanan informasi. Adanya sistem informasi berbasis komputer akan sangat membantu suatu instansi pendidikan untuk mendapatkan informasi yang cepat, tepat dan akurat dalam memberikan laporan.

Di Sekolah Menengah Pertama (SMP)

Putra Pertiwi, proses pengolahan data administrasi sekolah tidak sepenuhnya dilakukan oleh Tata Usaha, di antaranya dalam pembayaran sekolah Sumbangan Pengembangan Pendidikan (SPP) dan ekstrakulikuler dilakukan oleh staf yang terdiri dari beberapa orang guru, bagian Tata Usaha belum bisa bekerja secara menyeluruh dalam administrasi karena keterbatasan Sumber Daya Manusia (SDM) pada staf Tata Usaha yang masih manual, manual dalam hal ini ialah input data administrasi dengan mengunakan Microsoft office yaitu Microsoft excel dan hanya staf beberapa orang saja yang bis a dan mengerti, dalam penyimpanan data masih menggunakan buku besar, sehingga dalam hal ini membutuhkan media penyimpanan data transaksi yang sangat besar untuk seluruh siswa.

Berdasarkan uraian di atas, maka rumusan masalah dalam penelitian ini adalah bagaimana mengembangkan sistem informasi administrasi yang sistematis, dapat menghasilkan data dan 
informasi yang akurat serta cepat sehingga dapat mengurangi kesalahan pengolahan?

\section{LANDASAN TEORI}

Sistem adalah kumpulan dari elemen elemen yang berinteraksi untuk mencapai suatu tujuan tertentu [1]. Sistem menggambarkan suatu kejadian - kejadian dan kesatuan yang nyata adalah suatu objek nyata, seperti tempat, benda, dan orang - orang yang betul - betul ada dan terjadi.

Untuk memahami atau mengembangkan suatu sistem, maka perlu membedakan unsurunsur dari sistem yang membentuknya. Berikut adalah karakteristik sistem yang dapat membedakan suatu sistem dengan sistem lainnya:

a. Batasan (Boundary)

Batasan adalah pengambaran dari suatu elemen atau unsur mana yang termasuk di dalam sistem dan mana yang di luar sistem.

b. Lingkungan (Environment)

Lingkungan adalah segala sesuatu di luar sistem, lingkungan yang menyediakan asumsi, kendala, dan input terhadap suatu sistem.

c. Masukan (Input )

Input adalah sumber daya (data, bahan baku, peralatan, energi) dari lingkungan yang dikonsumsi dan dimanipilasi oleh suatu sistem.

d. Keluaran (Output)

Keluaran adalah sumber daya atau produk (informasi, laporan, dokumen, tampilan layar komputer, barang jadi) yang disediakan untuk lingkungan sistem oleh kegiatan dalam suatu sistem.

e. Komponen (Component)

Komponen adalah kegiatan-kegiatan atau proses dalam suatu sistem yang mentransformasikan input menjadi bentuk setengah jadi. Komponen ini bisa merupakan subsistem dari sebuah sistem.

f. Penghubung (Interface)

Penghubung adalah tempat komponen atau sistem dan lingkungannya bertemu dan berinteraksi.

g. Penyimpanan (Storage)

Penyimpanan adalah area yang dikuasai dan digunakan untuk tempat penyimpanan sementara dan tetap dari informasi, energi, bahan baku, dan sebagainya. Penyimpanan merupakan media penyangga di antara komponen yang bekerja dengan berbagai tingkatan yang ada dan memungkinkan komponen yang berada dari berbagai data yang sama.

Perancangan sistem adalah proses pengamatan terhadap keadaan suatu badan usaha dengan tujuan dapat mengetahui situasi operasionalnya dan apakah badan usaha tersebut memerlukan suatu perbaikan atau tidak yang meliputi identifikasi suatu masalah, analisa suatu masalah dan penyeleksian suatu masalah.[2] tujuan dari perancangan sistem adalah:

a. Untuk memberikan gambaran yang jelas dan rancang bangun yang lengkap kepada programmer dan ahli-ahli teknik yang terlibat.

b. Untuk memenuhi kebutuhan pemakai sistem.

Komponen-komponen perancangan secara umum sebagai berikut :

1. Perancangan Model

2. Perancangan Keluaran

3. Perancangan Masukan

4. Perancangan Basis Data

5. Perancangan Kontrol

Aplikasi yang dapat mendukung adanya sistem informasi. Aplikasi ini diantaranya bahasa pemrograman seperti PHP dan mySQL.

Pada awalnya, PHP dirancang untuk diintegrasikan dengan webserver Apache. Namun belakangan ini, PHP juga dapat bekerja dengan webserver seperti PWS (Personal Web Server), IIS (Internet Information Server) dan Xitami.

Yang membedakan PHP dengan bahasa pemrograman lain adalah adanya tag penentu, yaitu diawali dengan " $<$ ?" atau " $<$ ?php" dan diakhiri dengan "?>". Jadi kita bebas menempatkan skrip PHP dimanapun dalam dokumen HTML yang telah kita buat.Model kerja HTML diawali dengan permintaan suatu halaman web oleh browser.

Berdasarkan URL (Uniform Resource Locator) atau dikenal dengan sebutan alamat internet, browser mendapatkan alamat dari web server, mengidentifikasi halaman yang dikehendaki dan menyampaikan segala informasi yang dibutuhkan oleh webserver.Selanjutnya, webserver akan mencarikan berkas yang diminta dan memberikan isinya ke browser. Browser yang mendapatkan isinya segera melakukan proses penerjemahan kode HTML dan menampilkannya ke layer pemakai. 


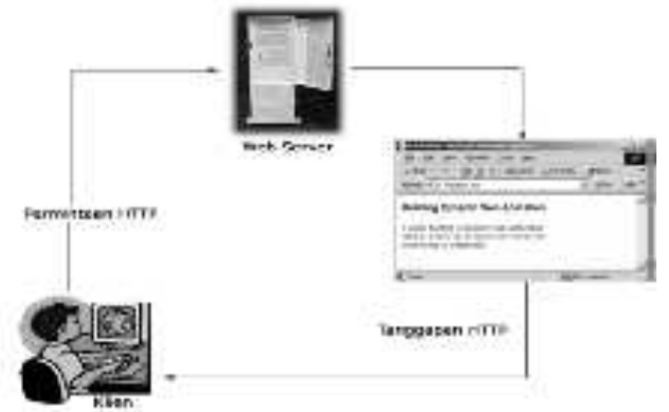

Gambar 1. Skema HTML

Bagaimana halnya kalau yang diminta adalah sebuah halaman PHP? Prinsipnya serupa dengan kode HTML. Hanya saja, ketika berkas PHP yang diminta didapatkan oleh webserver, isinya akan dikirimkan ke mesin PHP dan mesin inilah yang memproses dan memberikan hasilnya (berupa kode-kode HTML) ke webserver, untuk selanjutnya webserver menyampaika[n ke klien.

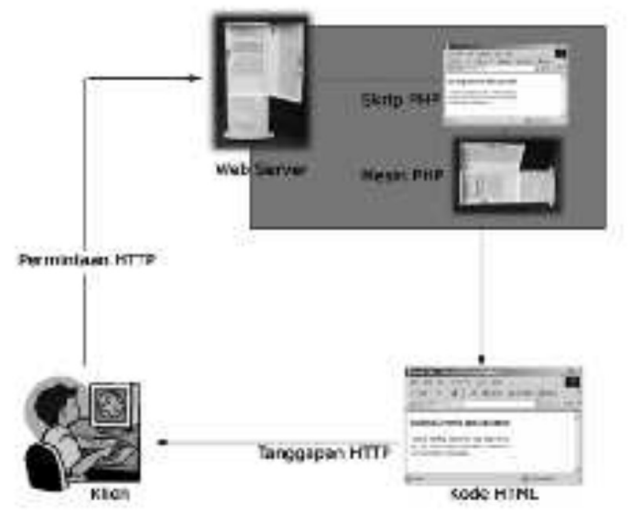

Gambar 2. Skema PHP

Salah satu kelebihan PHP adalah mampu berkomunikasi dengan berbagai database yang terkenal. Dengan demikian, menampilkan data yang bersifat dinamis, yang diambil dari database, merupakan hal yang mudah untuk diimplementasikan. Itulah sebabnya sering dikatakan bahwa PHP sangat cocok untuk membangun halaman-halaman web dinamis.

Pada saat ini PHP sudah dapat berkomunikasi dengan berbagai database, meskipun dengan kelengkapan yang berbedabeda, beberapa diantaranya adalah: DBASE, DBM, FilePro (Personix, Inc), Informix, Ingres, Interbase, Microsoft Access, MSQL, MySQL, Oracle, PostgreSQL, Sybase.

MySQL adalah salah satu jenis database server yang sangat terkenal. MySQL menjadi sangat populer karena MySQL bersifat free (tidak perlu membayar dalam menggunakannya) pada berbagai platform (unix/windows). (Sutarman, 2003). Untuk mendapatkan MySQL dapat didownload dari http://www.mysql.org atau www.mysql.com.

MySQL termasuk jenis RDBMS (Relational Database Management System). Pada MySQL, sebuah database mengandung satu atau sejumlah tabel. Tabel terdiri atas sejumlah baris dan setiap baris mengandung satu atau beberapa kolom.

Pada saat instalasi, secara default MySQL akan membuat sebuah database bernama mysql.

Salah satu isi dari database ini adalah tabel user, tabel ini berisi nama dan password user yang dapat mengakses data pada database yang dibuat di mysql.

Database ini juga berisi hak-hak yang diberikan pada setiap user.

a. Tipe data yang diterima oleh MySQL

MySQL menerima berbagai macam tipe data. Tipe-tipe data ini dibagi menjadi 3, yaitu: tipe data untuk bilangan, tipe data untuk tanggal dan jam, dan tipe data untuk karakter.

b. Fungsi-fungsi MySQL

Ada banyak fungsi yang dapat digunakan untuk mengakses database pada MySQL. Sebagian besar dari fungsi-fungsi tersebut menggunakan awalan "mysql". Dalam kesempatan ini peneliti akan mencoba memaparkan beberapa fungsi-fungsi tersebut.

\section{METODE PENELITIAN}

Pada analisis sistem ini ada beberapa tahapan uraian diantaranya adalah:

a. Analisa sistem yang sedang berjalan Pencatatan Data Siswa

Siswa SMP Putra Pertiwi angkatan baru terlebih dahulu harus mengisi form data diri siswa, kemudian data tersebut harus diserahkan kepada staf yang bersangkutan. Siswa secara langsung membawa Kartu SPP kepada bagian Tata Usaha, setelah itu staf Tata Usaha mencatat pembayaran yang di lakukan siswa tersebut, jika siswa tersebut tidak membawa kartu SPP maka staf Tata Usaha akan memberikan bukti pembayaran berupa bukti kwitansi dengan keterangan pembayaran yang di lakukan siswa tersebut.

\section{Proses Pembuaan laporan}

Staf Tata Usaha akan membuat sebuah laporan keuangan setiap priode tertentu, biasanya laporan akan dibuat setiap hari, 
minggu, dan bulanan. Setelah Staf Tata Usaha selesai membuat laporan, kemudian akan di serahkan kepada pimpinan atau ke Kepala Tata Usaha yang akan di teruskan ke Kepala sekolah

\section{b. Analisa Proses}

Kegiatan-kegiatan yang dilakukan oleh Bagian Tata Usaha dalam melaksanakan proses-proses Administrasi Tata Usah yang digambarkan dengan Activity Diagram.

\section{Proses Administrasi Siswa}

Activity Diagram Pencatatan Pembayaran Iuran Siswa

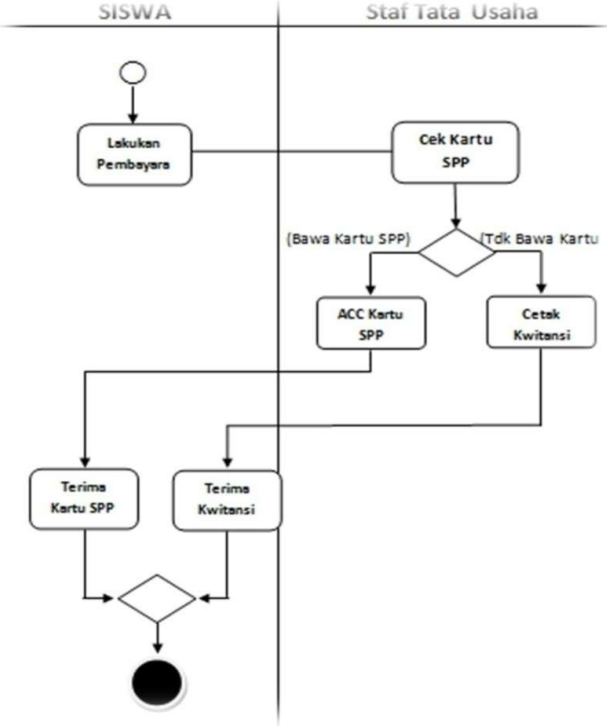

Gambar 3. Diagram Pembayaran Iuran Siswa

Proses pembuatan laporan

Proses pembuatan laporan

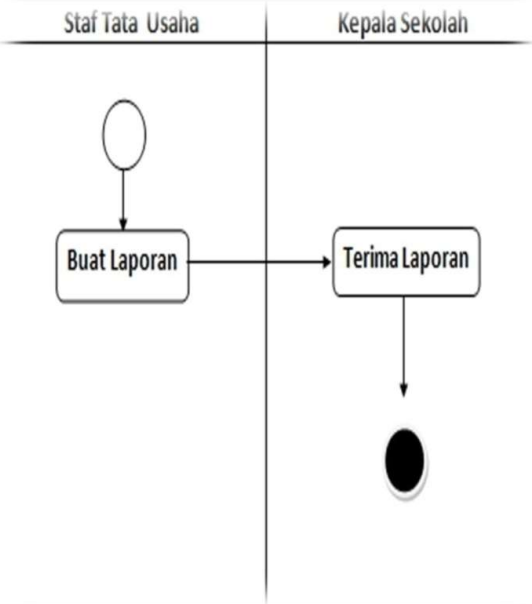

Gambar 4. Diagram Pembuatan Laporan

\section{c. Analisa Masukan}

Analisa masukan yang di hasilkan dari sistem yang berjalan adalah sebagai berikut:

Nama Masukan: Form Data Siswa

Sumber : Siswa

Fungsi : Digunakan untuk mengetahui data diri siswa yang bersekolah di SMP Putra Pertiwi

Media : Kertas

Rangkap : : (satu) lembar

Frekuensi : Setiap ada siswa yang baru masuk tahun ajaran yang baru

Format : Lihat lampiran B-1

Keterangan : Di buat untuk mengisi data diri siswa

Hasil Analisa : Sudah cukup baik sebagai bahan analisis

Nama Masukan: Kartu SPP

Fungsi : Sebagai bukti pembayaran iuran sekolah yang dimiliki oleh masing-masing siswa

Media : Kertas

Distribusi : Siswa

Rangkap : : 1 (satu) lembar

Frekuensi : Setiap ada siswa yang membayar iuran sekolah

Format : Lampiran B-2

Keterangan : Kartu SPP di buat oleh bagian Tata Usaha untuk di berikan kepada iswa, dan siswa membawanya setiap kali membayar iuran sekolah

Hasil Analisa : Sudah cukup baik keperluan Analisa

\section{d. Analisa Keluaran}

Analisa keluaran yang dihasilkan dari sistem yang berjalan sebagai berikut:

Nama Keluaran: Kwitansi

$\begin{array}{ll}\text { Fungsi } & \text { : Sebagai bukti } \\ & \text { pembayaran Siswa } \\ \text { Media } & : \text { Kertas } \\ \text { Distribusi } & : \text { Siswa,Staf } \\ \text { Rangkap } & : 2 \text { (dua) lembar } \\ \text { Frekuensi } & : \text { setiap terjadi } \\ & \text { pembayaran } \\ \text { Volume } & : \text { 20/bulan } \\ \text { Keterangan } & : \text { dibuat sebagai tanda } \\ & \text { bukti pembayaran }\end{array}$




\section{Hasil Analisa : Sudah cukup baik sebagai bahan analisa}

\section{IMPLEMENTASI}

Implementasi sistem informasi administrasi di SMP Putra Pertiwi ini dilakukan dengan menggunakan bahasa dan lingkungan pemrograman PHP dengan basis data yang digunakan adalah MySQL. Aplikasi tersebut dapat dijalankan pada berbagai platform sistem operasi dan perangkat keras, tetapi implementasi dan pengujian sepenuhnya hanya dilakukan pada perangkat keras PC (Personal Computer) dengan sistem operasi Microsoft Windows XP.

\section{Implementasi Perangkat Lunak yang digunakan}

Tabel 1.Rincian Kebutuhan Perangkat Lunak

\begin{tabular}{|l|}
\hline \multicolumn{2}{|c|}{ Jenis Perangkat Lunak } \\
\hline Windows XP Professional \\
SP2/ Linux \\
\hline MySQL versi $5.0 .27-$ \\
win32/Linux \\
\hline Apache v.2.2.6 \\
\hline
\end{tabular}

\section{Implementasi Perangkat Keras yang digunakan.}

Sistem perangkat keras yang digunakan harus memenuhi spesifikasi minimal sehingga mampu memenuhi kebutuhan hardware dari sistem yang aka diterapkan. Adapun spesifikasi hardware yang dibutuhkan oleh sistem ini adalah:

Tabel 2. Rincian Kebutuhan Perangkat Keras

\begin{tabular}{|l|l|}
\hline \multicolumn{2}{|c|}{ Perangkat Keras } \\
\hline Casing & Simbadda X-652 \\
\hline Power Supply & Antec NeoHE 550 \\
\hline Motherboard & $\begin{array}{l}\text { Disesuaikan dengan } \\
\text { processor }\end{array}$ \\
\hline Processor & Intel Pentium D 820 \\
\hline Memory & $\begin{array}{l}\text { Crucial PC2-3200 DDR2 } \\
\text { 4x512 MB) }\end{array}$ \\
\hline Hardisk & 250 GB 7200 SATA \\
\hline VGA & Integrated \\
\hline Optical Drive & $\begin{array}{l}\text { SAMSUNG } \\
\text { DVD writer }\end{array}$ \\
\hline Monitor & 15“ \\
\hline Mouse & PS2 Standard \\
\hline Keyboard & PS2 Standard \\
\hline Stabilizer & Standard \\
\hline
\end{tabular}

Implementasi Basis Data
Basis data yang telah mempunyai bentuk normal selanjutnya dijelaskan dalam spesifikasibasis data yang meliputi nama file, media penyimpanan yang digunakan, isi yang disimpan, organisasi yang digunakan, primary key, panjang record, jumlah record dan struktur.

a. File Siswa

Tabel 3. Siswa

\begin{tabular}{|c|l|l|c|l|}
\hline No & Nama Field & \multicolumn{1}{|c|}{ Jenis } & Lebar & Keterangan \\
\hline 1 & Nis & Varchar & 9 & No Induk \\
\hline 2 & id_kelas & Int & 3 & Id Kelas \\
\hline 3 & Nama & Varchar & 50 & Nama \\
\hline 4 & tempat_lahir & Varchar & 20 & Tempat \\
\hline 5 & tgl_lahir & Date & 8 & Tanggal \\
\hline 6 & Alamat & Varchar & 200 & Alamat \\
\hline 7 & jns_kelamin & Varchar & 9 & $\begin{array}{l}\text { Jenis } \\
\text { Kelamin }\end{array}$ \\
\hline
\end{tabular}

b. Struktur Tabel Kelas

Tabel 4. Kelas

\begin{tabular}{|r|l|l|l|l|}
\hline $\mathrm{N}$ & Nama & Jenis & Leba & Keteranga \\
\hline 1 & id_kelas & Int & 3 & ID Kelas \\
\hline 2 & nm_kela & Varcha & 10 & Nama \\
\hline
\end{tabular}

c. Struktur Tabel Iuran

Tabel 5. Jenis Iuran

\begin{tabular}{|c|l|l|l|l|}
\hline $\mathrm{N}$ & Nama & Jenis & Leba & Keterangan \\
\hline 1 & id_jenis & Int & 5 & ID Jenis \\
\hline 2 & nm_iura & Varch & 30 & Nama iuran \\
\hline 3 & hrg_baya & Decim & 10 & Harga \\
\hline 4 & jns_angg & Decim & 10 & Jenis \\
\hline
\end{tabular}

d. Sturktur Tabel Bayar

Tabel 6. Bayar

\begin{tabular}{|c|l|l|l|l|}
\hline N & Nama & Jenis & Leba & Keteranga \\
\hline 1 & no_iuran & Varcha & 6 & No Iuran \\
\hline 2 & id_jenis & Int & 5 & ID Jenis \\
\hline 3 & jml_baya & Decima & 10 & Jml Bayar \\
\hline 4 & sisa_baya & Decima & 10 & Sisa Bayar \\
\hline
\end{tabular}

e. Struktur Tabel Jenis Kwitansi

Tabel 7. Kwitansi

\begin{tabular}{|c|l|l|l|l|}
\hline N & Nama & Jenis & Leb & Keterangan \\
\hline 1 & no_kwita & Varch & 6 & No Kwitansi \\
\hline 2 & tgi_kwita & Date & 8 & Tanggal \\
\hline 3 & no_iuran & Varch & 6 & No Iuran \\
\hline
\end{tabular}


f. Struktur Tabel Anggaran

Tabel 8. Anggaran

\begin{tabular}{|l|l|l|l|l|}
\hline No & Nama Field & Jenis & Leba & Keteranga \\
\hline 1 & id_anggaran & Int & 5 & Id \\
\hline 2 & nm_anggara & Varcha & 30 & Nama \\
\hline
\end{tabular}

\section{Implementasi Aplikasi}

Pembuatan Database sistem pada sistem dibuat berdasarkan ERD yang telah dibuat. Pembuatan database dalam sistem aplikasi administrasi pembayaran keuangan sekolah berbasis dekstop ini menggunakan PHP MyAdmin 3.2.4.

Pada layout yang telah didefinisikan pada bab perancangan terdapat beberapa layout untuk sistem ini, diantaranya adalah tampilan untuk login sistem, halaman utama, tampilan menu file master, halaman entri jenis anggaran, halaman entri jenis iuran, halaman entri data kelas,halaman entri data siswa, halaman tabel data siswa, halaman form pembayaran iuran dan halaman bukti kwitansi penerimaan

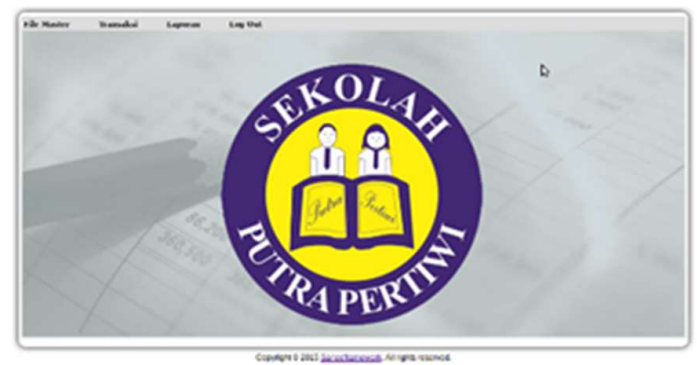

Gambar 5. Halaman Login

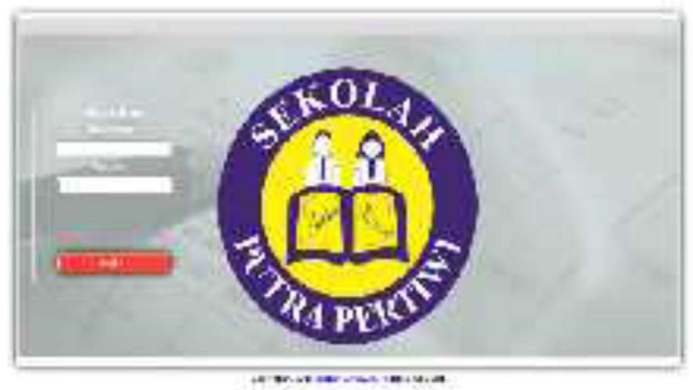

Gambar 6. Halaman Utama

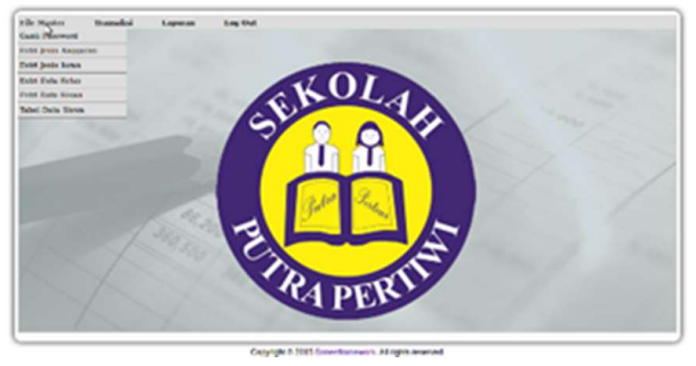

Gambar 7. Menu File Master

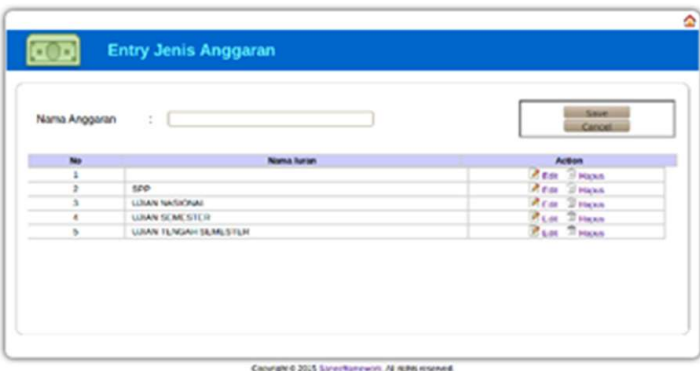

Gambar 8. Entri Jenis Anggaran

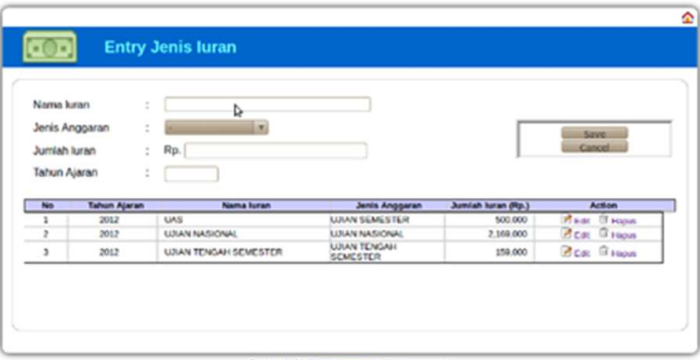

Gambar 9. Entri Jenis Iuran

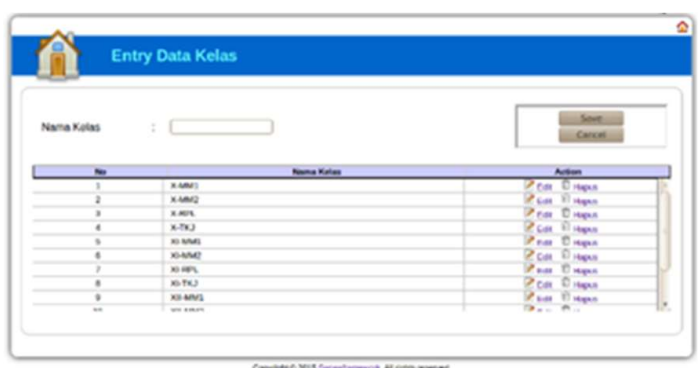

Gambar 10. Entri Data Kelas

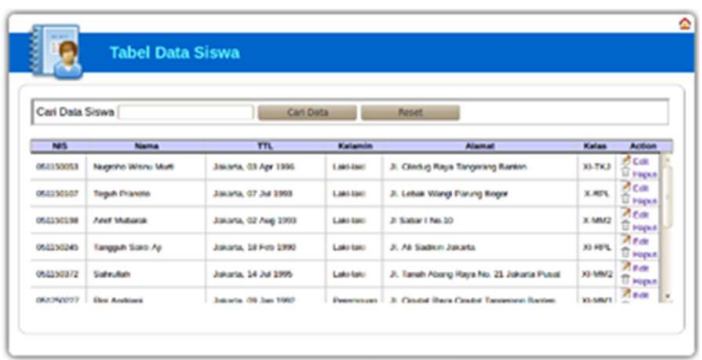

Gambar 11. Entri Data Siswa 


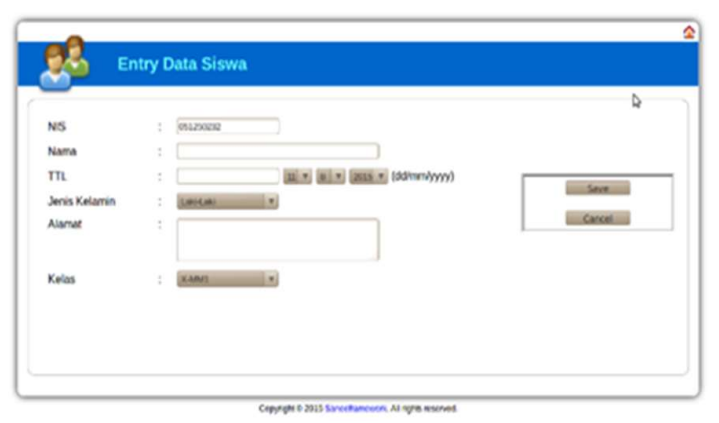

Gambar 12. Data Siswa

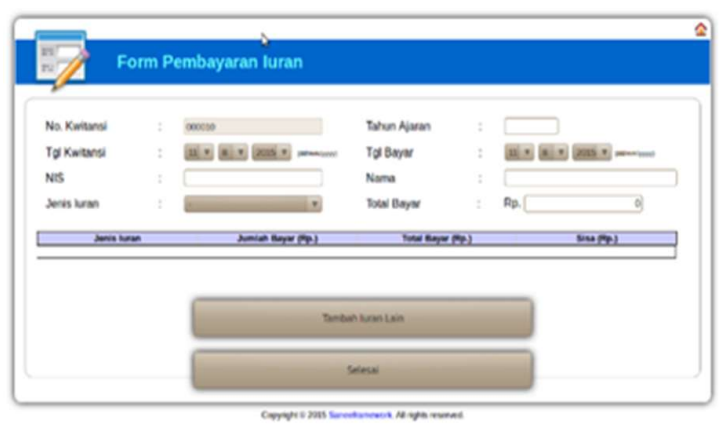

Gambar 13. Form Pembayaran Iuran

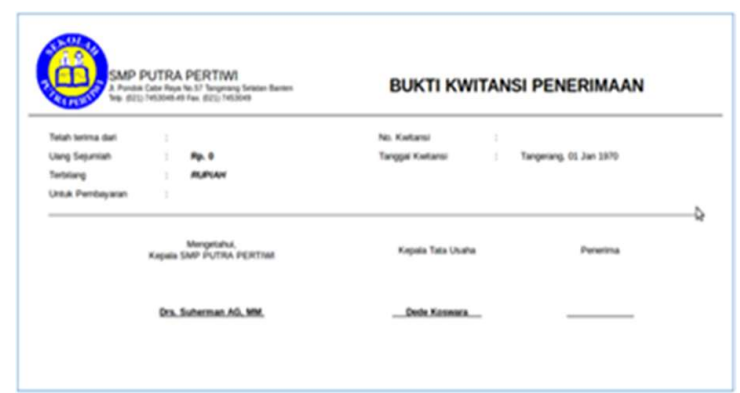

Gambar 14. Tampilan Bukti Kwitansi Penerimaan

\section{PENGUJIAN}

Pada pengujian sistem dilakukan pengujian dengan menggunakan metode pengujian black box. Pengujian pertama merupakan pengujian alpha sedangkan pengujian kedua merupakan pengujian beta.

\section{Pengujian alpha}

Pengujian alpha dilakukan oleh pembangun sistem. Pengujian alpha dilakukan untuk mengetahui apakah sistem yang dibangun masih memiliki eror pada sistem atau tampilan. Dalam pengujian alpha dilakukan pengujian terhadap beberapa fungsi yang sudah di buat pada sistem.Fungsi-fungsi yang diuji adalah: tambah data, ubah data, hapus data, cari data, lihat data, cetak laporan. Hasil pengujian alpha adalah:
Tabel 9. Pengujian Alpha

\begin{tabular}{|c|l|l|}
\hline No & $\begin{array}{c}\text { Fungsi yang } \\
\text { Diuji }\end{array}$ & \multicolumn{1}{|c|}{ Hasil Pengujian } \\
\hline 1 & Lihat Data & $\begin{array}{l}\text { Fungsi lihat data } \\
\text { berfungsi baik }\end{array}$ \\
\hline 2 & Tambah Data & $\begin{array}{l}\text { Fungsi tambah } \\
\text { data berfungsi baik }\end{array}$ \\
\hline 3 & Hapus Data & $\begin{array}{l}\text { Fungsi hapus data } \\
\text { berfungsi baik }\end{array}$ \\
\hline 4 & Cari Data & $\begin{array}{l}\text { Fungsi lihat data } \\
\text { berfungsi baik }\end{array}$ \\
\hline 5 & Ubah Data & $\begin{array}{l}\text { Fungsi ubah data } \\
\text { berfungsi baik }\end{array}$ \\
\hline 6 & Cetak Data & $\begin{array}{l}\text { Fungsi cetak } \\
\text { laporan berfungsi }\end{array}$ \\
\hline
\end{tabular}

\section{Pengujian Beta}

Pengujian beta merupakan pengujian yang dilakukan oleh pengguna sistem. Pada pengujian beta ini dilakukan pengujian pada beberapa fungsi yang tersedia pada sistem.

Berikut adalah hasil dari pengujian beta yang dilakukan.

Tabel 10. Pengujian Beta

\begin{tabular}{|c|c|c|c|}
\hline Nama & Posisi & $\begin{array}{l}\text { Fungsi } \\
\text { yang } \\
\text { diuji }\end{array}$ & $\begin{array}{c}\text { Hasil } \\
\text { Pengujian }\end{array}$ \\
\hline \multirow[b]{4}{*}{$\begin{array}{l}\text { Ani R, } \\
\text { Adm }\end{array}$} & \multirow[b]{4}{*}{$\begin{array}{c}\text { Staff } \\
\text { Administ } \\
\text { rasi }\end{array}$} & $\begin{array}{l}\text { Lihat } \\
\text { Data }\end{array}$ & $\begin{array}{l}\text { Fungsi lihat } \\
\text { data berfungsi } \\
\text { baik }\end{array}$ \\
\hline & & $\begin{array}{l}\text { Tambah } \\
\text { Data }\end{array}$ & $\begin{array}{l}\text { Fungsi tambah } \\
\text { data berfungsi } \\
\text { baik }\end{array}$ \\
\hline & & $\begin{array}{l}\text { Hapus } \\
\text { Data }\end{array}$ & $\begin{array}{l}\text { Fungsi hapus } \\
\text { data berfungsi } \\
\text { baik }\end{array}$ \\
\hline & & Cari Data & $\begin{array}{l}\text { Fungsi lihat } \\
\text { data berfungsi } \\
\text { baik }\end{array}$ \\
\hline & & $\begin{array}{l}\text { Ubah } \\
\text { Data }\end{array}$ & $\begin{array}{l}\text { Fungsi ubah } \\
\text { data berfungsi } \\
\text { baik }\end{array}$ \\
\hline & & $\begin{array}{c}\text { Cetak } \\
\text { Laporan }\end{array}$ & $\begin{array}{l}\text { Fungsi cetak } \\
\text { lap berfungsi } \\
\text { baik }\end{array}$ \\
\hline
\end{tabular}

\section{KESIMPULAN}

Kesimpulan penelitian ini adalah berdasarkan implementasi dan pengujian yang dilakukan, metode Water Fall dapat diterapkan pada sistem informasi administrasi sekolah atau pembayaran sumbangan pengembangan pendidikan (SPP) berbasis desktop dengan beberapa tahapan yatiu mulai dari tahapan analisis sistem, kebutuhan sistem, perancangan sistem, pengembangan sistem sampai ke tahapan 
pengujian sistem dan dilanjut ke tahap implementasi sistem. Dengan tahapan-tahapan waterfall di atas maka sistem administrasi sekolah SMP putra pertiwi dapat dikembangkan dan diterapkan.

\section{DAFTAR PUSTAKA}

[1] Hartono, J. (1999). Analisis dan Desain Sistem Informasi Edisi ke-2. Yogyakarta

[2] Hartono, J. (2000). Pengenalan Komputer dan Sistem Informasi. Yogyakarta

[3] David , Powers. (2006). PHP Solutions: Dynamic Web Design Made Easy. Friendsof ED an Apress Company. New York, United States of America.

[4] Madcoms.(2007). Teknik Mudah Membangun Website dengan HTML, PHP dan MySQL. Madiun

[5] Munawar. (2005). Pemodelan Visual Dengan UML. Penerbit Graha Ilmu. Yogyakarta

[6] Kadir Abdul. (2008). Dasar Pemrograman Web Dinamis Menggunakan PHP. Andi.Yogyakarta.

[7] Lano, Kevin. (2009). UML 2 Semantics And Applications. John Wiley\& Sons, Inc. Hoboken, New Jersey

[8] Gunawan, Wahyu. (2010). Kebut Sehari jadi Master PHP. Genius. Yogyakarta.

[9] Podeswa , Howard. (2010). UML for the IT Business Analyst, Second Edition: A Practical Guide to Requirements Gathering Using the Unified Modeling Language. Course Technology PTR. Channel Center Street Boston, MA 02210 USA. 